\title{
THE PERPETUATION OF A SYSTEM OF CONFLICTS IN DARFUR: CAUGHT BETWEEN LOCAL VIOLENCE AND REGIONAL DISORDER
}

\author{
Amandine Gnanguênon ${ }^{1}$ \\ Institut de recherche stratégique de l'Ecole militaire
}

\begin{abstract}
:
In many cases in Africa, armed and non-armed local conflicts, taken separately, interact to the point of creating what can be called "complexes" or "systems". If some of the concepts may help us to define the regional dimension of local conflicts, they do not provide us with a better understanding of the overlapping of several conflicts. Taking the example of Darfur between 2003 and 2011, this article sheds light on how violence and disorder arose and developed both at local, national and regional levels. It proposes an empirical demonstration of the originality and relevance of the concept of system of conflicts, with the aim of opening a debate on current research on definitions of conflict and war trough the African prism.
\end{abstract}

Keywords: System of Conflicts, War, Regional Security, Darfur, State, Africa.

\section{Resumen:}

En muchos casos en África, los conflictos locales armados y no armados, considerados por separado, interactúan hasta el punto de crear lo que puede llamarse "complejos" o "sistemas". Si bien algunos de los conceptos nos pueden ayudar a definir la dimensión regional de los conflictos locales, no nos proporcionan una mejor comprensión acerca de la superposición de varios conflictos. Tomando el ejemplo de Darfur en el periodo entre 2003 y 2011, este artículo contribuye a aclarar cómo la violencia y el desorden surgieron y se desarrollaron, tanto a nivel local como nacional y regional. El artículo propone una demostración empírica de la originalidad y la pertinencia del concepto de sistema de conflictos, con el objetivo de abrir un debate en la investigación actual sobre las definiciones de conflicto y guerra desde un prisma africano.

Palabras clave: Sistema de conflictos, guerra, seguridad regional, Darfur, Estado, África.

Copyright $\odot$ UNISCI, 2013.

Las opiniones expresadas en estos artículos son propias de sus autores, y no reflejan necesariamente la opinión de UNISCI. The views expressed in these articles are those of the authors, and do not necessarily reflect the views of UNISCI.

\footnotetext{
${ }^{1}$ Amandine Gnanguênon is a Research Fellow on African issues at the Institute for Strategic Research at the Ecole militaire (IRSEM) and holds a PhD in Political Science from the University of Auvergne, Clermont Ferrand.Dr Gnanguênon has a theoretical and operational expertise of regionalism (Regional Economic Communities) and regionalization of conflicts in Africa. She is also project manager of War and Politics (Guerre\&Po), Emergences Program 2012 (winning project of Paris City Hall). Her main research areas are: African Regional Economic Communities, war in Africa, system of conflicts, security regionalism. IRSEM, case 46, 1 place Joffre, 75007 PARIS.

Email: amandine.gnanguenon@gmail.com.
}

http://dx.doi.org/10.5209/rev_UNIS.2013.n33.44810 


\section{Introduction}

An overview of the conflicts on the African continent ${ }^{2}$ leads to the observation that in many cases armed and non-armed conflicts spill over state borders. We suggest qualifying that phenomenon as a "system of conflicts". In the 1990s, Liberia, Sierra Leone and Guinea provided a first illustration of this ${ }^{3}$ and there are no shortages of recent examples in West Africa, Senegambia, the Gulf of Guinea and the Sahel ${ }^{4}$ — not to mention Somalia in the Horn of Africa ${ }^{5}$; the eastern region of the Democratic Republic of Congo (DRC) to the frontier of the Great Lakes sub-region ${ }^{6}$, and Darfur, at the crossroads of Central Africa (Chad) and Eastern Africa (Sudan). The difficulty here is to succeed in describing the way in which the various conflicts, taken separately, interact to the point of creating what some academics call conflict "complexes" or "systems".

Barry Buzan was one of the first researchers to suggest an analysis in terms of Regional Security Complex Theory (RSCT). He defined this as "a group of states whose primary security concerns link together sufficiently closely that their national securities cannot realistically be considered apart from one another. Security complexes tend to be durable, but they are neither permanent nor internally rigid". ${ }^{7}$ That approach, by considering that internal conflicts in states are linked together by security issues, is a starting point. Following Buzan's work, which inspired numerous authors, some explanations may help us to understand the regional dimension ${ }^{8}$ of conflicts.

Raimo Väyrynen has suggested the concept of Regional Conflict Formations $(R C F)$ : “A complex mix of violent, intra-national, intra-regional and extra-regional conflicts. The formation of these conflicts becomes more complex and entangled in the sense that they cannot easily become unraveled into individual conflicts. ${ }^{9}$ Peter Wallensteen and Margareta Sollenberg took this further with Regional Conflict Complexes (RCF), which they defined as "situations where neighboring countries experience internal or interstate conflicts, and with significant links between the conflicts. These links may be so substantial that changes in conflict dynamics or the resolution of one conflict will have an effect on a neighboring conflict". 10

\footnotetext{
2 This phenomenon is not peculiar to Africa, take for example Iraq (1980-1988, 1990-1991), Lebanon (19751989), the Balkans and Afghanistan. On these subjects, see the works by Armstrong, Andrea and Rubin, Barnett: "Conference summary: Policy Approaches to Regional Conflict Formations", Center on International Cooperation, 20 November 2002.

${ }^{3}$ See "Liberia, Sierra Leone, Guinée: la régionalisation de la guerre", Politique Africaine, n88 (December 2002), pp.5-102.

${ }^{4}$ See the works by Massaër Diallo within the framework of the Sahel West Africa Club (SWAC) and also for the Institut d'Etudes Politiques et Stratégiques (IEPS) at http://www.ieps-cipsao.org.

${ }^{5}$ The Horn of Africa comprises Somalia, Djibouti, Ethiopia and Eritrea.

${ }^{6}$ The Great Lakes Region comprises the Democratic Republic of Congo, Burundi, Uganda and Rwanda.

${ }^{7}$ Buzan, Barry (1983): People, States and Fears, The National Security Problem in International Relations, Brighton, Harvester Press, pp. 105-115.

${ }^{8}$ My approach to the region corresponds to the "macro-region", also known as "world region", defined as a territorial unit or sub-system located between the state level and that of the global system. Söderbaum, Frederik (2003): Introduction: Theories of New Regionalism, in Theories of New Regionalism, Palgrave reader, Basingstoke, Palgrave Macmillan, p. 6.

${ }^{9}$ Väyrynen, Raimo: "Regional Conflict Formations: An Intractable Problem of International Relations", Journal of Peace Research, vol. 21, n (November 1984), p. 344.

${ }^{10}$ Wallensteen, Peter; Sollenberg, Margareta: “Armed Conflict and Regional Conflict Complexes, 1989-97?", Journal of Peace Research, vol. 35, n5 (September 1998), p. 623.
} 
Taking these attempted definitions as a starting point, two common factors need to be mentioned. First the proponents of $R S C$ and $R C F$ question the impact of outside intervention, whether direct or indirect, on the intensity of a conflict. According to Väyrynen, "the origin of conflict formations are, in other words, explained by domestic conditions, while factors external to the region may account, for instance, for the intensity and duration of violent conflicts" 11 These links emphasize that the state is essential to understanding the interaction between the internal and external dimensions of regional conflicts. We may therefore deduce that state borders, being the visible manifestations of the principles of sovereignty and territoriality, are where the political, social and economic interactions are strongest.

At this stage of our review of the literature on the subject, two questions remain. If forms of regional conflict can resemble civil wars or border disputes ${ }^{12}$, how are we to distinguish them from a civil war with third party intervention? Does a regional conflict have its own specific characteristics? To provide some elements of an answer it is necessary to review in greater detail the notion of a "system" so complex that we cannot separate the different components of the conflict. Our approach pays special attention to the notion of a system ${ }^{13}$, defined "as a set of elements in interaction". ${ }^{14}$ According to the interdependence principle, a system depends both on the evolution of those internal elements and on external pressures. The main difficulty in understanding how the system is created lies in identifying the various conflicts that produced it (its internal components) and understanding their interdependence on other conflicts for which it was not directly responsible (its external components).

In the 1990s, a round table was organized for analyzing the dynamics of conflict perpetuation, which suggested a comparative approach in terms of war systems. Didier Bigo, one of the organizers, stressed the importance of the links between the militarized actors in understanding how the system is perpetuated. According to Bigo, "the militarized actors have ambiguous ties with each other and dominate the third parties in the conflict, such as the civilian population, and the unarmed actors. They generate new fronts and borders that have a two-fold function, namely to delimit the conflict zones (to circumscribe or foreclose them) and above all to impose a socio-political order on the unarmed inhabitants by submitting them to various warlords". ${ }^{15}$ Didier Bigo's approach, more descriptive than analytical, introduces the idea into the debate that the perpetuation of a conflict "legitimizes" or rather justifies, the use of violence. In short, within the framework of a war system, armed conflict becomes a strategy for obtaining material rewards. The control of resources and territory is an important factor for armed groups and influences the political sphere. Combat is characterized by its endurance rather than by its intensity. The longer a war lasts, the more an unconscious mimicry sets in among the belligerents. Since they do not aim for major military action, they develop defensive strategies to maintain a form of local power.

A few years later Roland Marchal and Christine Messiant perfected the definition of a war system by describing it as: "armed conflicts produced by distinct national circumstances

\footnotetext{
${ }^{11}$ Väyrynen, op. cit., p. 352.

12 Ibid., p.345.

${ }^{13}$ Meszaros, Thomas: "Quelques réflexions sur l'idée de système en sciences sociales et sur son utilisation dans les Relations internationales contemporaines”, Cosmopolitis, n² (2007).

${ }^{14}$ Bertalanffy, Ludwig Von (1973): Théorie générale des systèmes, Physique, biologie, psychologie, sociologie et philosophie, Paris, Dunod, p. 3.

15 Round table on "La prolongation des conflits: Approche comparative des systèmes de guerre", Cultures \& Conflits, ${ }^{\circ} 1$ (1990), at http://conflits.revues.org/147.
} 
and caused by different actors, modalities and issues that serve to blur the spatial, social and political lines that originally distinguished them. Such conflicts begin to resonate and interact with each other, consequently transforming the conditions for duplication and, more importantly, the parties confronting each other, the issues of the struggle and the objectives sought. Such intricacies of armed civil and international violence create a system and makes the actors' reasoning extremely complex, obscuring the play of alliances, which in turn have no logic". ${ }^{16}$ This perspective stresses the fact that interstate wars are closely linked to civil conflicts whose reach extends beyond the local framework. These authors also stress the simultaneous re-composition of geographic, social and political space in the system to clarify the differences between them and those in the original conflict. In our case, for example, we must distinguish Darfur province from the Sudan-Chad-Libya "tri-state" and consider how it was organized in the existing system of conflicts. Having demonstrated the contribution of research, albeit relatively poor, in terms of complexes and war systems, I should like to present the starting point of my proposal, namely a first definition of a system of conflicts.

Whereas on the ground the theoretical distinction between war and conflict tends to disappear, the complementary approaches to war systems mentioned above, do lead challenge the links between war and conflict, understood as a sociological phenomenon internal to a given society. In other words, the socio-political dimension of a system is the result of the overlap of characteristics specific to given wars and conflicts. Thus some researchers call war systems conflict systems. ${ }^{17}$ That semantic change appears inevitable given that the reference to the notion of conflict from the sociological dimension is particularly relevant in the social sciences. Conflict, being more adaptable, includes war, which represents the armed aspect, while also providing us with a better understanding of the regional or even trans-national aspect. ${ }^{18}$ Thus a system of conflicts enables us to question the links between armed and nonarmed conflicts.

Based on the above, this paper proposes an empirical demonstration of the originality and relevance of this concept, with the aim of opening a debate on current research on definitions of conflictuality in Africa by suggesting that certain concepts in international relations be revisited. Here I should add that my research framework was Darfur province from 2003 to 2011, a period when the system of conflicts was most visible. Indeed, the situation in Darfur only acquired international visibility after the media coverage of 2003. Furthermore, while tensions fell after the Doha Agreement of July 2011, some conflicts sporadically reappeared. It is difficult to trace the contours of this system of conflicts geographically, given that it is part of an ancient three-cornered relationship between Chad, Sudan and Libya, which goes beyond mere inter-state relations. "The frontier between Libya, Chad and Sudan is a hostile environment. Its history, ethnic loyalties and religious commitments have defined the responsibilities of those who, by means of their birthright or ability, were supposed to lead. Like the chiefs, they often opted for their own survival rather

\footnotetext{
${ }^{16}$ Marchal, Roland; Messiant, Christine: "Une lecture symptomale de quelques théorisations récentes des guerres civiles", Lusotopie, vol.13, no. 2 (2006), pp. 1-48.

17 Bazenguissa Ganga, Remy (2003), "Les réfugiés dans les enjeux locaux dans le Nord-Est du Congo" in Guichaoua André: Les migrants forcés en Afrique centrale et orientale, Paris, Karthala, pp. 379-423. Marchal, Roland: "Soudan d'un conflit à l'autre“, Etude du CERI, n¹07-108 (September 2004). Marchal, Roland: "Tchad/Darfour: vers un système de conflits“, Politique africaine, n¹02 (June 2006), pp. 135-154.

18 Armstrong, Andrea; Rubin Barnett: "Conference Summary: Policy Approaches to Regional Conflict Formations", Policy paper series (November 2002). Leenders, Reinoud: “Au-delà du "Pays des deux fleuves": une configuration conflictuelle régionale ?", Critique internationale, vol.1, no. 34 (2007), pp. 61-78.
} 
than that of their successors. Many of them seized the opportunities ironically supplied by drought and war, to ensure their own promotion and preservation". ${ }^{19}$

Before shedding light on how the system of conflicts arose and developed in Darfur province between 2003 and 2011, I will reiterate three points. First I should like to review the origins of the system of conflicts in Darfur. Then I will query the way in which the international expansion of the conflict since 2003 acted as a catalyst and contributed to the changes in the geographical limits of the system. Certainly the situation in Darfur can only be understood by integrating the same logic to the bordering countries, so I will pay special attention to the established links between the various players. That will enable us to conclude on the parameters that now suggest a link between the system of conflicts in Darfur and the nature of the state, or in other words, how the lack of legitimacy of a regime in place, despite its electoral legality, confers legitimacy on those who demand their rights to justice, security and access to national resources.

\section{The Internal Roots of the System of Conflicts in Darfur}

In certain aspects, the roots of the system of conflicts in Darfur lay both in its recent history and in the British colonial system, leading to the interaction of at least two series of conflicts. A first series was based on intricate internal land rights tensions as well as tensions between this outlying province and the central political Sudanese power, based in Khartoum. The second series reverberated with the effects of a conflict resulting from the reconfiguration of other wars involving Sudan, such as the rebellions in Chad and the Sudanese civil war between the central government and the SPLA. Here we must view the system of conflicts in time as well as in space.

\subsection{The Recurrent Practice of Proxy Wars on a Regional Scale}

From 1966, when FROLINAT (The Chad National Liberation Front) was established, Darfur was at the center of a triangular Sudan-Chad-Libya relationship. ${ }^{20}$ By establishing itself in Nyala, in Darfur, FROLINAT made that province a sanctuary for opponents to successive regimes in Chad (Goukouni Weddei, Hissène Habré, and Idriss Déby). For FROLINAT West Sudan was a more easily exploitable rear base than the Central African Republic or Nigeria. Successive victories by the Chad rebel forces in their country would doubtless not have occurred without the support of Sudan and above all, Libya.

In order to obtain allies, FROLINAT had no compunction about echoing the "antiimperialist" discourse of the Sudanese and Libyan heads of state. Sudan's commitment can be understood as a strategy for fighting the southern Chad regime of president Tombalbaye, which discriminated between the Muslim populations in the north, the center and the east of the country. The revolutionary momentum and frenetic pan-Arabism that Muammar Gadhafi hoped to spread around the region, justified his appearance on the scene. In November 1969, two months after he came to power, FROLINAT opened bases in Libya. Gadhafi continually manipulated the ethno-political landscape in Darfur using a logic that pitted the "Arab" populations against the "Negro-African" ones.

\footnotetext{
${ }^{19}$ Burr, Millard; Collins, Robert (1999): Africa's Thirty Years war: Libya, Chad, and the Sudan 1963-1993, Boulder, Colo. Westview Press, p.5.

${ }^{20}$ Ibid.
} 
Two events further complicated the situation for the central Sudanese government: Hissène Habré seized power in Chad in 1982, and in 1983 the rebellion in oil-rich South Sudan, resumed ${ }^{21}$, opposing the central government and the Sudan People's Liberation Army (SPLA). Libya and Sudan found common ground for agreement in order to deal with these situations. Sudan, in need of weapons and cash to fight the war, allowed Libya to use Darfur as a rear base to overthrow the new president of Chad. Meanwhile the government in Khartoum had been using militia to fight the SPLA since 1985, because of the high cost of maintaining an army, mainly composed of people originally from Darfur. In South Sudan the rationale of forming local militia, sometimes in rivalry against each other, was used year after year. $^{22}$

The arrival of Idriss Déby in Sudan in 1989 (until then the Chad advisor on defense and security), following his failed coup against Hissène Habré, intensified the three-cornered conflict between Chad, Libya and Sudan. Déby's efforts to form a military force with which to seize power in Chad led to the social and military polarization of the entire province of Darfur. ${ }^{23}$ The Chad army increased the number of raids on the Chad-Libyan militia camps there, either to attack them or in retaliation for the recurrent strikes. During those years, the regular Sudanese army was not involved in Darfur. It was struggling to hold on to its positions in the south and was unable to fight the Libyans or the militia supported by them. The situation stabilized when a ceasefire agreement was signed with the SPLA in 2002 followed by a demilitarization process. However, this had an impact on the land rights conflict already underway in Darfur.

\subsection{Land Conflicts in Darfur}

Tensions had existed in Darfur province since colonial times, which created an environment that favored growing political, economic and social insecurity. The political marginalization of the province dates to its integration with Sudan in 1916. Khartoum's relationship with Darfur was one of opposition between the center, which held the monopoly of power and wealth, and the periphery. That was reflected in the alienation of the electorate. From the 1940s, the inhabitants of Darfur backed Rahman al-Mahdi who promoted total independence for Sudan. That resulted in Darfur province being side-lined and heightened people's resentment against the government, which they perceived as monopolizing the national wealth. The Anglo-Egyptian Condominium that effectively controlled the country's colonization was a perfect illustration of a system of administration by "indirect governance". The people appointed to various administrative posts in the "indirect" administration were often incompetent, illiterate and corrupt, and quite incapable of providing for people's needs by implementing economic, administrative or social development program. Since Sudan's independence on 1 January 1956, successive governments progressively relinquished their obligations to the inhabitants of Darfur by reducing government budgets in health, education, and other basic services while continuing to levy taxes, recruit soldiers for the army and exploit a cheap labor force. ${ }^{24}$

Darfur province had always functioned as an autarky, with the merchants' role primarily devoted to long-distance trade and relations with the government. As the inhabitants' socioeconomic expectations rose, this agricultural-pastoral autarky was challenged. The absence of

\footnotetext{
${ }^{21}$ The war had lasted from 1955 to 1972.

${ }^{22}$ Marchal, "Soudan d'un conflit à l'autre“, op. cit.

${ }^{23}$ Marchal, "Tchad/Darfour: vers un système de conflits“, op. cit.

${ }^{24}$ Tanner, Victor: "Darfour: racines anciennes, nouvelles virulences", Politique étrangère, n 4 (April 2004), p.717.
} 
any redistribution of the national wealth, when the survival of the regime depended on its oil revenues, further aggravated the frustrations of a population that was totally marginalized and increasingly less willing to accept its situation of poverty. From the 1970s Darfur's environmental degradation was another cause for concern. Drought and growing desertification exacerbated the inhabitants' already precarious situation. Environmental insecurity triggered food insecurity, both of which affected the relationship between the nomadic and the sedentary populations. Access to land became the subject of tensions between them, while the watering holes and pasturelands on the migratory routes in the north, together with the richer and better watered lands of the south, were coveted by groups in search of new migratory routes or dar (land) on which to settle. ${ }^{25}$ The demographic pressure on those coveted areas created an imbalance in the distribution of land.

In the 1980s, the land rights system, established by the Sultanate of Darfur in the 17th century, was totally overhauled to create a legal system that distinguished between the agricultural communities, most of which had land rights, and the nomadic cattle-rearing population, which did not. ${ }^{26}$ The authority of the farmers (Zaghawa, Masalit, Rizeigat) was recognized, and they were entitled to claim a right of way or usufruct, against the payment of a tithe on their harvest. The nomadic herdsmen in turn benefitted from migratory zones and camps, stipulated by negotiation - for instance, they had to ask the indigenous peoples for permission before settling near a well. During periods of tension disputes that had formally been settled by common law, ceased to depend on that framework since its legitimacy was contested, leading to a crisis that echoed the pre-existing political, economic and social frailties.

Land tensions destroyed a way of life that had been regulated by common law. After the disappearance of the northern pastures the nomads headed south too early and the farmers, who had yet to bring in their harvests, refused them access to their land. The nomads, now perceived as invaders, proceeded to attack the farmers and force their way across their lands. They even allowed their cattle to feed on their fields, already ravaged by drought. Among the nomads' grievances, was that the farmers had burnt weeds to improve soil fertility, instead of giving them to their starving cattle. The farmers in turn organized themselves to defend their land by force.

At the same time as the land rights conflict, divisions were occurring between ethnic groups. Identity definition had never been a priority for the patchwork of peoples that make up Darfur province. The "Darfurien" identity, which transcended ethnicity, now disintegrated to the benefit of the Arab/non-Arab divide. ${ }^{27}$ Social grievances began to be expressed by combining the two attributes, opposing the "Arab" herdsmen and the "non Arab" farmers. Furthermore, the loss of their cattle due to drought convinced the Arabs that they needed their own land. In Darfur, Masalit and Fur self-defense groups were formed to protect against incursions by Janjaweed militia, who were to play an important role in the emergence of Darfurian rebel groups later. In Chad, where people were traditionally armed with bows and poison-tipped arrows or spears, the Dajo militia collected money from the civilian population and attempted to buy firearms from both the Sudanese rebels and the Chad army. They finally succeeded in arming themselves. The capacity of the local militia should not be overestimated, since it comprised groups of young people from various villages who came

\footnotetext{
${ }^{25}$ Tubiana, Jérôme: "Le Darfour, un conflit pour la terre ? “, Politique africaine, $\mathrm{n}^{\circ} 101$ (March 2006), pp. 111131.

${ }^{26}$ Ibid.

${ }^{27}$ Tubiana, Jérôme: “Le Darfour, un conflit identitaire?”, Afrique contemporaine, n 214 (February 2005), pp. 165-206.
} 
together to carry out collective work in agriculture or for constructing homes, to celebrate festivals or to fight wars. ${ }^{28}$

\subsection{State Intervention and the Militarization of the System of Conflicts}

The disintegration of the "Darfurian" identity provided the government with an opportunity to seize the initiative for military intervention in the province. Its involvement prevented any hope of a return to some kind of status quo that may have been achieved with the appropriate political responses. With a minimum amount of prevention, money and, above all, political good will on the part of Khartoum, it would have been possible to prevent the escalating insecurity in Darfur. The inter-community conflict related to rights of way and land use, required rapid decisions from the Sudanese government. Although the government had expressed no interest in the local population until then, it decided to use the crisis to tighten its control over Darfur, and did so by exploiting the rivalries and differences that were flaring up, as in the case of land ownership. The government's stance hastened the redefinition of the many, complex relationships individuals and communities had with their land and their attachment to it and their own identity.

In 2003, an insurrection broke out in Darfur just when the power struggle between the central government and the Sudan People's Liberation Army (SPLA) in South Sudan was drawing to an end and Idriss Déby, who had come to power in Chad in 1990, was attempting to dismantle the rebel forces. As I mentioned earlier, at the time the Khartoum government relied on a national army (composed for the most part of people from Darfur) to fight in South Sudan. These demilitarization processes served to reconfigure the situation in Darfur.

On 25 February 2003, the Darfur Liberation Front (FLD), led by Abdel Wahid Mohamed Nur, launched an insurrection in the Jebel Marra, to the west of Sudan. Originally composed of Four village self-defense groups, it took the name of Sudan Liberation Army (SLA) in March that year to highlight the presence of other communities such as the Masalit, the Zaghawa and Berti within it. The SLA was well-trained and benefited from the experience of its military leader, Abdallah Abakkar, who had helped Idriss Déby take power in Chad in 1990. Abakkar's trajectory reveals how some actors succeeded in transferring their war experience in Chad to armed struggle in their own provinces. The rebels seized Golo in Jebel Marra, where they established their headquarters and Tine on the border with Chad. They became credible players when they seized the airport in El Fasher (the capital of North Darfur) on 25 April 2003 and captured General Ibrahim Bushra, the Sudanese air force commander. In North Darfur, a second group also stood out, the Movement for Justice and Equality (MJE), composed of Zaghawa and headed by Doctor Khalil Ibrahim. ${ }^{29}$ Despite the ceasefire signed in September 2003, the war continued and spread to the border regions.

The Sudanese government became aware of the power struggle with the Darfur rebel groups, former village self-defense bodies that had become political players. Their change of identity helped to transform the earlier intra-community conflict into a war. The rebels' capacity to intervene in the political arena was, in the eyes of the Darfur inhabitant, a consecration of the loss of legitimacy of the Sudanese government. The government's inability to cater to their demands and ensure fair and non-partisan order, made the use of force for demanding their rights to their representatives, legitimate in their eyes.

\footnotetext{
${ }^{28}$ Tubiana, Jérôme: "The Chad-Sudan Proxy War and the 'Darfurization' of Chad: Myths and Reality“, Small Arms Survey, $\mathrm{n}^{\circ} 12$ (April 2008).

${ }^{29}$ For more detail on the history of the formation of those two groups, see Marchal, "Soudan d'un conflit à l'autre", op. cit.
} 
In 2003, a portion of the loyalist troops engaged in South Sudan became available. The government was now able to reinforce the army and take the offensive. However, since it could not use the national army to intervene, given that it was largely composed of people originally from Darfur, it played on the rift in Darfurian identity. The government decided to arm the Janjaweed and give it a free hand in attacking the rebel villages. These warriors "came from the most part from the small camel-driving tribes in the north of Darfur, impoverished and marginalized, who did not obtain dar from the British colonial authorities and were suffering the effects of climate change and ecological deterioration". 30

The attacks were often led jointly with the Sudanese national air force while the Janjaweed pursued their raids. Although the conflict did not spread to the point of opposing "Arabs" and "Africans" (to put it simply), it did turn into a civil war that extended beyond just a few villages. "Poverty and greater competition for decreasing resources, a way of life and survival in conflict, the abundance of weapons and armed communities, the absence of any mediating authorities and the presence of an aggressive state, meant that Darfur was ripe for an explosion". 31

Darfur became the arena for an armed conflict that was of particular concern to the government. Because the population in the province was poor and had nothing to lose, it proved to have warlike qualities that could jeopardize the government. From the outset the government's main fear was to find itself in a compromising situation should any alliance be formed between the rebels in the South and those in Darfur. Its response to the rebellion in Darfur was therefore brutal in order to be exemplary, and that violence prolonged the effects of the massive deterioration in people's living conditions over several decades. On 9 February 2004 President Omar El Bechir declared his loyalist army's victory and announced the end of military operations. But although the army had regained control of the towns, the fighting and the massacre of civilians continued. In 2005, a peace agreement was signed under pressure from the international community, and the United States in particular.

\section{Local, National, Regional, International: A Multi-Scale Conflict}

While the conflict in Darfur was already taking place on a local and national scale, it went international in 2003. Intensified combat attracted the attention of the international community, which further reinforced the system of conflicts. The question then, is to find out whether or not international intervention had an impact on the duration and intensity of the violence in a province where the power struggle between players was already marked by the practice of proxy wars at regional level, and how the various conflicts overlapped.

\subsection{International Intervention as a Catalyst in the System of Conflicts?}

Starting out from the idea that conflict formation is always defined and influenced by the interests of the players, it is worth remembering the international context in which the Darfur crisis occurred. In February 2003, the seriousness of the war there timidly emerged on the international media scene. At the time the UN agencies were focused on Iraq and North Korea, was well as the United Nations Mission in Côte d'Ivoire (MINUCI) and the deployment of Operation Artemis in the Democratic Republic of Congo. Furthermore, the

\footnotetext{
${ }^{30}$ Tanner, op.cit., p.722.

${ }^{31}$ Ibid., p.720.
} 
Khartoum government took care to conceal events in a province that was closed to foreign observers including international agencies and journalists. ${ }^{32}$

It was not until December 2003 that the "major Western powers, mediators and observers in the negotiations underway in Kenya at the time, [decided] to express themselves on the escalating conflict in a remote area of Sudan. The considerable time lag between the crisis bursting onto the media stage and its recognition at diplomatic levels gave the impression that Darfur was inviting itself to the negotiating table". ${ }^{33}$ Darfur was threatening the "peacemaker" image that Khartoum sorely needed for its negotiations with the Sudan People's Liberation Army (SPLA). Negotiations were carried out under the watchful eye of the United States, the first country to take a firm position against Sudan in January 2004. The US not only sought a conclusion to the peace talks with the South but a ceasefire agreement and discussions with all the Sudanese rebel movements.

The internationalization of the Darfur issue accelerated with the growing accusations of genocide against the Khartoum government. That had particular resonance in April 2004 when Rwanda commemorated the $10^{\text {th }}$ anniversary of the genocide. It is important to note that from the start, this crisis entered the international area as a result of a collision between two time scales and the instrumentalization by political leaders of the "anniversary syndrome". ${ }^{34}$ That alarm signal caught the attention of Western leaders and public opinion, concerned about the impact such a crisis might have if it were to deteriorate further. Mukesh Kapila, United Nations Humanitarian Coordinator for Sudan, provided the media with an opportunity to focus on the image of refugees. By choosing victimization as an angle to inform about the situation, the international community provided the Khartoum government with a means for attracting attention and then appropriating international aid. Aid could only be put in place by negotiating with the Sudanese government, which had no compunction about regularly expelling any NGOs it considered undesirable. In 2006, it even refused access to Darfur to Jan Egeland, the UN Under-Secretary General for Humanitarian Affairs. Khartoum's objective was to win time by profiting from the international community's inconsistent political actions, which put the humanitarian organizations in the front line. While waiting for political decisions, the Darfur problem was treated as a humanitarian emergency.

Meanwhile, the massive displacement of people and the refugees fleeing the civil war in Darfur led to a public health crisis. People found themselves in camps with insufficient water supplies and the poor hygiene led to epidemics of diarrhea and other mortal diseases. Nevertheless, the real issue in that major humanitarian theater was the safety of the refugees. Making the camps secure proved to be a major problem for the international bodies, since the Janjaweed, now incorporated in the army and police force, were charged with protecting the population, and they used the refugee camps to extend their zone of influence and supply themselves with food, men and weapons. New towns appeared out of nowhere and camps became veritable tinderboxes. ${ }^{35}$ The NGOs were not only hostage to the Sudanese political power games but victims of rebel attacks themselves. Khartoum exploited the complexity of the situation by claiming that it was unable to achieve the objectives imposed by the international community. For instance, Resolution 1556, adopted on 22 July 2004, which gave

\footnotetext{
${ }^{32}$ Fontrier, Marc (2009): Le Darfour: organisations internationales et crise régionale: 2003-2008, Paris, l'Harmattan, p. 21.

${ }^{33}$ Marchal, "Soudan d'un conflit à l'autre", op. cit., p. 38.

34 Ancelin Schützenberger, Anne (1993): Ä̈e, mes ä̈eux!: liens transgénérationnels, secrets de famille, syndrome d'anniversaire et pratique du génosociogramme, Paris, La Méridienne, p. 194.

${ }^{35}$ Fontrier, op. cit., p. 221.
} 
the Sudanese government until 30 August to disarm the Janjaweed militia, was deemed unrealistic by Khartoum.

Growing public condemnation, threats of oil embargos and restrictions on the movements of certain government officials in Khartoum, identified as being responsible for the crimes committed in Darfur, had no effect. Even though the situation in Darfur had been referred to the International Criminal Court less than three months after the Comprehensive Peace Agreement in the South (2005), the Sudanese regime pursued confrontations on two fronts, the one political and the other military. Khartoum was continually double-dealing the rebels in Darfur as well as the international community, which it perceived as being dangerously partial to rebel demands. Throughout the Darfur peace negotiations, the Sudanese regime exploited the antagonisms between the most interventionist countries on the one hand, and China, Russia and the League of Arab States on the other, as well as the United Nations (UN) and the African Union (AU), which were sharply divided.

Even after the African Union's Mission to Sudan (AMIS) was deployed, it was continually discredited by the continual time lag between the commitments taken, the declarations of intent and the actual achievements. From May 2004 to December 2007, AMIS' objective was to establish a more suitable peacekeeping force that was better equipped by the UN, but the Sudanese government objected. AMIS had neither the means nor the experience, and its mission grow more complex day by day. The cooperation between the various parties committed to it was a makeshift institutional attempt to bring some coherence to the military, political and humanitarian operations.

Despite the support of its partners, the AU's main difficulty proved to be financing the mission and once it reached a dead end with empty coffers, the pan-African organization had no choice but to transfer the operation to a United Nations peace force. However, under the AMIS mandate, now incorporated into the African Union/UN Hybrid Operation (UNAMID) in 2007, the law and order situation in Darfur scarcely improved. The AU had committed itself under difficult conditions and in a context when most of the Sudanese protagonists did not fully cooperate with AMIS, and regularly and deliberately broke their commitments. Above all, Sudan benefitted from solidarity and sympathy within the African Union, which constituted a serious obstacle to any approach vetoed by Khartoum.

The warring factions' reactions to the announcement that operations were being transferred from the AU to the UN were ambiguous. The divided rebels feared seeing the poorly equipped African contingents replaced with well-trained troops that might challenge their predatory economy, while the Sudanese government "did not want to see trained contingents, which might prevent it from pursuing a complex strategy that aimed to cut their losses in South Sudan by maintaining other revolts in a state of dormant war". ${ }^{36}$ After long negotiations the international community succeeded in making the Sudanese government accept the principle of a "hybrid" AU/UN force. Despite having precise functions, its global and more ambitious objectives required a longer-term commitment. The Security Council's Resolution 1769 stated that UNAMID must "protect its personnel, facilities, installations and equipment, and to ensure the security and freedom of movement of its own personnel and humanitarian workers". At the same time its intervention was meant to help create an environment favorable to economic reconstruction and development prior to the lasting return of the displaced populations. To carry out this mission UNAMID had to deal with a Sudanese government that discussed peace with diplomats and journalists, while pursuing the war.

\footnotetext{
${ }^{36}$ Ibid., p. 217.
} 
UNAMID suffered from a lack of resources (tactical transportation, aerial reconnaissance, land transport, engineers, logistics, medical supplies and means for broadcasting), which affected the execution of its mandate. Its rules of engagement were limited, as was its deployment, including in the refugee camps.

UNAMID helped Sudan to integrate former rebels into the army, set up economic governance and transitional justice. The obstacles it faced were, ultimately, the result of the Sudanese government's ambiguous relationships (arming militia, exploiting humanitarian assistance, etc.). UNAMID's DDR mission (disarmament, demobilization and reintegration) led to other issues. For instance, how was it possible to disarm tribal chiefs who traditionally bore arms? Indeed, “ [...] All nomads have a quasi-mystical relationship with weapons in general and their own in particular, whether these are knives, assegai, bows and arrows or assault rifles. To removing a weapon is tantamount to an act of castration. These may be worn without munitions, since they are frequently in short supply, but the weapon is there, inalienable, by the man's side, a symbol of his strength, courage, and virility, and a part of himself just as much as his right hand. To demand that he hand it over can only trigger a process of revolt and intolerable torment. On the other hand, a far more subtle, but also more plausible, exercise would be to negotiate that the weapons remain in its holster and to regulate supplies of munitions". ${ }^{37}$ Another issue was how to end a conflict in a state where one regime after another had based its legitimacy on arms, as was the case in Chad?. ${ }^{38}$ At the intersection of those two dimensions, another dynamic of the conflict situation in Darfur was exacerbated by the proxy wars carried out on a regional scale.

\subsection{Return to the Regional Dimension of the System of Conflicts in Darfur}

From a purely political point of view, the crises in Chad and Sudan during the 2000 decade were not connected at the outset. The situation in Darfur was the result of a Sudanese political crisis, while Chad under Idriss Déby was facing an internal political conflict whose origins had no direct link with Darfur either. Indeed, Déby's crisis of legitimacy prevented him from containing ethnic solidarity with the Zaghawa engaged in the Sudanese revolt within his own entourage. However, the changing situation and certain specific circumstances led to the two internal conflicts overlapping. Two factors in the Sudanese crisis further regionalized the conflict: the arrival in Chad of many Sudanese refugees and the incursions of the Janjaweed militia into Chad territory in pursuit of the rebels who had sought refuge in camps there. Increasing episodes of violence occurred on both sides of the Chad-Sudan border with the displacement of populations, destruction of villages, clashes among the insurgent groups, and attacks on refugee camps.

Relations between Chad and Sudan gradually deteriorated. Each country's political exploitation of the events acted as a catalyst on their own domestic crises. In short, the Chad regime supported the Sudanese rebellion, which recruited in the Chad refugee camps, while the Khartoum government used internal rifts within Idriss Déby's ethnic group and supported the Chad opponents present in Sudan. It became increasingly difficult to find any political agreement between the two countries because of each one's double-dealings. Any attempt to

\footnotetext{
${ }^{37}$ Ibid., p. 49.

38 Debos, Marielle: "Les limites de l'accumulation par les armes. Itinéraires d'ex-combattants au Chad", Politique africaine, $\mathrm{n}^{\circ} 109$ (May 2008), pp. 167-181. Debos, Marielle: "Fluid Loyalties in a Regional Crisis: Chadian combatants in the Central African Republic", African Affairs, vol. 107, n 427 (April 2008), pp. 225241.
} 
reach cooperation agreements on law and order failed until the Doha agreement was finally signed in July 2011.

The ties between Chad, Sudan and Libya illustrate Buzan's Regional Security Complex Theory (RSCR) in its most limited dimension. ${ }^{39}$ Within a RSC, states have relationships characterized as much by forms of voluntary cooperation as by a growing interdependence related to the nature of the security issues. Security matters lead to involuntary effects that result in unintended costs or benefits affecting states that were not involved at the outset. ${ }^{40}$ Whereas the intra-state trade has positive consequences, the displacement of populations and refugees are examples of repercussions with destabilizing effects in terms of the political, economic and social costs they engender. The originality of RSCT lies in the fact that it takes into account the interdependence of actors in geographical proximity, as well as interactions with more distant ones. ${ }^{41}$ Furthermore, because of their regional commitment, some "external" actors can be perceived as being part of a Regional Security Complex. For instance, the French presence in central Africa, and notably in Chad and the Central African Republic, is generally taken into account in analyzing regional power relations.

Another specificity of RSCT is that it eradicates the distinction between the internal and external spheres to the benefit of a logic of interlinked conflicts. When states face growing competition, political regimes play on several levels by re-appropriating cross-border solidarity, exploiting family ties between political players, and concluding alliances between armed groups - all of which can serve an established regime for placing and creating a clientelistic network. The transformation of a war is therefore the result of both the actors themselves and their interdependent relationships.

Far from being a simple established fact or a temporary situation, the instability that reigned on Darfur's borders was transformed into a political instrument ${ }^{42}$ and its exploitation fuelled the formation of a war/peace continuum in which violence became commonplace. After the clashes between the center and the periphery, the break-up of factions, and the proxy war with Chad with its repercussions on the Central African Republic, a new area of conflict was created that evolved in accordance with historic ties between populations and shifts in alliances. As in the case of Darfur, this was not disorder in the sense of anarchy, that is to say the absence of chiefs or synonymous with chaos. Rather it was a process by which certain actors sought to maximize their interests in a context of confusion and uncertainty that characterizes certain African countries. ${ }^{43}$ The perpetuation of that state of instability was as much due to the implication of the political powers - as illustrated by the relations between Chad, Sudan and Libya - as that of non-state actors. The communities located on either side of the Chad-Sudan border, mobilized for war, helped perpetuate the insurrection. ${ }^{44}$ Independently of state strategies, the modes of action by individual groups often occurred at the intersection of different rationales, such as the coming together of the Chad and Sudanese

\footnotetext{
${ }^{39}$ Defined as "a group of states whose prime security concerns are so closely linked that the security of any one cannot be separated from the others", Buzan, Barry, op. cit., p. 190.

${ }^{40}$ Lake, David; Morgan, Patrick (1997): Regional orders: building security in a new world, University Park, Pa., Pennsylvania State University Press, p. 48.

${ }^{41}$ For the purpose of this paper I have only discussed the relationships between three states, but others can also be considered integral to RSCT: the Central African Republic, Uganda, with the Lord's Resistance Army, The Democratic Republic of Congo, Eritrea - because of its former support to the Eastern Front rebels in Sudan - and South Sudan. I cannot develop all these aspects here since they go beyond the scope of this paper.

${ }^{42}$ Chabal Patrick; Dalloz, Jean-Pascal (1999): Africa Works: Disorder as a Political Instrument, London, International African Institute.

${ }^{43}$ Ibid., p. xviii.

${ }^{44}$ Marchal, "Tchad/Darfour: vers un système de conflits", op. cit., p.139.
} 
Zaghawa. Alliances were tactical and makeshift, and coherence a relative matter given their ambiguous and versatile nature. ${ }^{45}$ To grasp the regional dimension of the conflict it is necessary to bear in mind that the states, like the non-state actors, promoted their own interests. However, regional conflict formation still raises the question of how such conflicts overlap.

\subsection{The Issue of Overlapping Conflicts}

Given the various factors mentioned above, the question that must now be answered is how conflicts in different national spaces end up overlapping with each other. It is important from the start to dismiss the conflict mimicry thesis based on the idea that the same factors produce the same effects from one state to another. Indeed, the system of conflicts as it appeared in Darfur in 2003 was the consequence of the overlapping of at least two political conflicts in Chad and Sudan, each of which depended on its own individual factors There was no "Darfurization" process in Chad. ${ }^{46}$

We will, however, stick to the thesis by which conflicts inter-weave and propagate through socially-rooted networks. In the social sciences it should be remembered that, "networks designate poorly institutionalized movements uniting individuals and groups in an association under variable terms that are subject to reinterpretation according to the constraints on its actions. Networks are social organizations comprising individuals or groups whose dynamics aims to perpetuate, consolidate and advance the activities of its members in several socio-political spheres". ${ }^{47}$

Barnett Rubin pursues that idea with his notion of Regional Conflict Formation (RCF), which raises the idea of "network war". He defines RCF as "sets of violent conflicts - each originating in a particular state or sub-region - that form mutually reinforcing linkages with each other throughout a broader region, making for more protracted and obdurate conflicts" 48 Rubin's model proposes an analysis based on "four - often overlapping - types of transnational border-crossing networks: military (facilitating the flow of arms and combatants), economic (pertaining to cross-border trade in "'conflict goods') and social (defined by occupational, familial and diaspora affiliations and based on cross-border shared identities)". ${ }^{49}$ Such networks certainly existed in Darfur. The military and security dimension of a network makes cross-border movement possible, through which arms and combatants pass whether or not they receive support from the border states. Existing solidarity between heads of state since the 1960s provided a concrete form for the political network, which evolved according to the protagonists' regional claims. The existence of an economic and financial network was there with the various types of trafficking on the Chad-Sudan border. Last, solidarity between members of the Zaghawa ethnic group on both sides of the border, demonstrates the existence of a social network. However, analyzing conflict overlap in terms of networks alone would fail to take into account the way the networks impact conflict formation.

\footnotetext{
${ }^{45}$ Bach, Daniel; Sindjoun, Luc: “Ordre et désordre en Afrique”, Polis, vol. 4, n² (1997).

${ }^{46}$ Tubiana, "The Chad-Sudan Proxy War and the 'Darfurization' of Chad: Myths and Reality", op. cit. Debos, op. cit.

${ }^{47}$ Colonomos, Ariel (1995): Sociologie des réseaux transnationaux. Communautés, entreprises et individus: lien social et système international, Paris, l'Harmattan, p. 22.

${ }^{48}$ Rubin, op.cit.

${ }^{49}$ Ibid.
} 
The network analysis model was taken up by Reinoud Leenders and applied to the Middle East. ${ }^{50}$ According to Leenders, the transnational nature of conflicts, erroneously qualified as internal, is not specific to Africa or the Balkans. He believes that the central issue in the analysis of the propagation of conflicts is the gradual disappearance of the existing limits between various internal conflicts. Based on his case studies in Iraq, Syria and Lebanon, Leenders demonstrates the limitations of RCF. He believes that this analytical framework does not provide sufficient explanations about the way the various factors cause, stir up, or prolong conflicts. By wanting expand Marie Kaldor's approach in terms of "new wars" "51, Barnett Rubin only identified four networks. According to Leenders a central component in the vectors of conflicts is missing, namely the social and political representations, which he calls "symbolic political capital". He defines this as "the capacity of all political actors to create a cognitive socio-political space that is recognized and respected by a sufficiently broad public. In this way, the actors impose their concept and views of events and processes that were fundamentally contentious at the outset". 52

The notion of symbolic political capital seems relevant in the case of Darfur for two reasons. Once the conflict emerged, the difficulty in returning to a statu quo ante was due to the impression that "[...] in people's minds, the interests of all the parties were now less and less reconcilable. The 'Arabs' were those who had refused to deal with the threatening famine, and they (or their Libyan allies) had refused to distribute weapons to their 'brothers' in Darfur with which to kill the 'African' peasants. It was also their fault that the civil war in Chad had spilt over to Darfur. For the 'Arab' nomads, the black peasants were simply a threat to their pastoral survival and it was necessary to eliminate by all possible means that obstacle formed by a backward people practicing a 'dubious Islam'. 53 Furthermore, since international intervention was being exploited by local actors, it had become an integral part of the system of conflicts. By acting on people's perceptions, intervention acquired legitimacy. Perceptions of intervention were constantly shaped by people's hopes or deceptions requiring responses from the peacekeeping forces to the political and military upheavals the population was subjected to. That paradoxical effect was the result of the lack of neutrality and legitimacy of any intervention in the political process, indissociable from times of war. ${ }^{54}$

\section{Conclusion: System of Conflicts in Darfur and the Formation of the State}

The system of conflicts in Darfur between 2003 and its settlement in 2011 was the result of several components overlapping. First, a number of non-armed conflicts intensified over time to the point of spilling beyond the local framework in which they started. Next, the province became militarized, creating a breeding-ground for civil war due to the absence of settlement by peaceful means and the desire of several border countries to profit from the instability. Last, the system of conflicts was perpetuated, since each conflict provided opportunities for numerous actors seeking support in defending their own interests.

\footnotetext{
${ }^{50}$ Leenders, op. cit.

${ }^{51}$ Kaldor, Mary (1999): New and old wars: organized violence in a global era, Stanford, Stanford University Press.

${ }^{52}$ Leenders, op. cit., p.70.

${ }^{53}$ Prunier, Gérard (2005): Le Darfour, un génocide ambigu, Paris, La Table ronde, p. 138.

${ }^{54}$ Mbembe Achille: "Essai sur le politique en tant que forme de la dépense", Cahiers d'études africaines, $\mathrm{n}^{\circ}$ 173-174 (2004), pp 151-192.
} 
The analysis of the system of conflicts in Darfur raises another question, namely the role of the state. We have started out with the hypothesis that a system of conflicts is an expression of a specific type of state. War is not a phenomenon that opposes states but "contributes to the emergence of a 'system of states' on a regional scale, as it did in Europe until the first half of the $20^{\text {th }}$ century" " 55 . Relations between states can evolve to become conflictual when the parties attempt to obtain satisfaction by resorting to violence as the most profitable option. Chad's intervention in the Sudan conflict and vice versa enabled the two countries to develop their military capacity and conclude agreements in line with their strategic and economic interests. States are all the more tempted to resort to violence if they feel vulnerable because of the instability of their borders.

Geographic contiguity causes political, economic, historical and cultural links, and the strategy of the actors, to have a significant impact on their neighbors, as in case of the relationship between Chad, Sudan and Libya. In addition to geographic proximity, history and shared culture, recurrent hostility and rivalry also favor the creation of alliances of circumstance between actors. War provides states with the possibility of recovering a portion of national legitimacy that was weakened by their partisan practices. The gradual erosion of legitimacy confers de facto legitimacy on rebel groups claiming certain rights. Whatever the external influences on a system, the central issue is that of the state's ability to create legitimacy within that system without resorting to violence. As with the confrontations in Darfur, the exacerbation of political conflicts and their regionalization could be interpreted as a state-forming process rather than an expression of its decline. If the violence is perceived as a means for a state to impose a form of regional equilibrium, the system of conflicts in Darfur can reappear at any time through the reconfiguration of alliances between those states and the armed groups. The perpetuation of the system of conflicts in Darfur could be related to the fact that it also acted as a means of political and economic control over the power game between the various actors.

\footnotetext{
${ }^{55}$ Bayart, Jean-François: "La guerre en Afrique formation ou dépérissement de l'Etat? République sud-africaine, Congo-Kinshasa, Guinée-Bissau”, Esprit, nº 247 (1998), p. 63.
} 